\title{
REPRESENTAC̣̃̃ES SOCIAIS DOS LICENCIANDOS SOBRE O ESTÁGIO CURRICULAR SUPERVISIONADO
}

CAROLINE ANTUNES ROSA ${ }^{*}$

https://orcid.org/0000-0002-3292-1950

ADEMIR JOSÉ ROSSO2*

https://orcid.org/0000-0002-7143-0433

ADRIANO CHARLES FERREIRA ${ }^{3}$ ** https://orcid.org/0000-0002-3918-3006

RESUMO: O objetivo do artigo foi discutir as Representações Sociais (RS) de Licenciandos sobre o Estágio Curricular Supervisionado (ECS). Participaram da pesquisa 90 licenciandos dos terceiros e quartos anos das Licenciaturas de Matemática, Geografia e Biologia. As informações foram coletadas em questionário e entrevistas semiestruturadas. O referencial teórico é da abordagem estrutural de Abric e a dimensional de Moscovici. A análise estrutural das respostas dos questionários aplicados aos licenciandos de Matemática e Geografia indicou planejamento e aprendizagem como centrais nas RS do ECS. A análise dimensional das entrevistas com os Licenciandos de Biologia indicou atitudes favoráveis, contraditórias e desfavoráveis associadas a imagens de complexidade e dinamismo. O ECS é representado pelos licenciandos de Biologia como ambíguo, aplicação técnica e experiência pessoal.

Palavras-chave: Formação inicial; Estágio Curricular Supervisionado; Prática docente.

\section{REPRESENTACIONES SOCIALES DE LOS LICENCIADOS SOBRE LA PASANTÍA CURRICULAR SUPERVISADA}

RESUMEN: El objetivo del artículo fue discutir las Representaciones Sociales (RS) de licenciandos sobre la Pasantía Curricular Supervisada (PCS). Participaron de la investigación 90 licenciandos del tercero y cuarto años de las licenciaturas en la Matemática, Geografía y Biología. Las informaciones fueron recolectadas cuestionario y entrevistas semiestructuradas. El referencial teórico es el del abordaje estructural de Abric y la dimensional de Moscovici. El análisis estructural de las respuestas

\author{
"Licenciada em Biologia pela \\ Universidade Estadual de Ponta \\ Grossa (UEPG) e Mestranda em \\ Ciências Biológicas (Biofísica) \\ pelo Instituto de Biofísica \\ Carlos Chagas Filho da Universidade \\ Federal do Rio de Janeiro (UFRJ). \\ E-mail:<carolalixandre@gmail.com>. \\ "Doutor em Educação pela \\ UFSC. Pós-doutor em Psicologia \\ (Psicologia Social) pela UFSC. \\ Professor de Estágio Curricular \\ Supervisionado e do Programa de \\ Pós-graduação em Educação \\ da UEPG, Líder do Grupo de \\ Pesquisa em Educação e Formação \\ de Professores (Ponta Grossa). \\ E-mail:< ajrosso@uepg.br >. \\ ‘* Doutorando em Educação \\ pela UEPG. Professor de Geografia \\ na Educação Básica da Rede \\ Estadual do Paraná. Participante \\ do Grupo de Pesquisa Educação e \\ Formação de Professores (Ponta Grossa). \\ E-mail:< adrianogeopg@gmail.com>.
}

\footnotetext{
${ }^{1}$ Universidade Federal do Rio de Janeiro, Rio de Janeiro, RJ - Brasil.

2 Universidade Estadual de Ponta Grossa, Ponta Grossa, PR - Brasil.

${ }^{3}$ Universidade Estadual de Ponta Grosa e Secretaria Estadual de Educação, Ponta Grossa, PR - Brasil.
} 
de los cuestionarios aplicados a los licenciandos de la Matemática y la Geografía indicó planificación y aprendizaje como centrales en las RS de la PCS. El análisis dimensional de las entrevistas con los licenciandos de la Biología indicó actitudes favorables, contradictorias y desfavorables asociadas a imágenes de complejidad y dinamismo. La PCS es representada por los licenciandos de la Biología como ambigua, aplicación técnica y experiencia personal.

Palabras clave: Formación Inicial; Pasantía Curricular Supervisada; Práctica Docente.

\section{UNDERGRADUATE STUDENTS' SOCIAL REPRESENTATIONS OF THE SUPERVISED CURRICULAR INTERNSHIP}

ABSTRACT: The goal of this article is to discuss the Social Representations (SR) of undergraduates on Supervised Curricular Internship (SCI). 90 undergraduates participated in the study, students of the third and fourth years of Mathematics, Geography and Biology Degrees. The information was collected in a questionnaire and semistructured interviews. The theoretical background was the Structural Approach by Abric and the Moscovici's Dimensional Approach. The structural analysis of the questionnaires' answers applied to the undergraduates of Mathematics and Geography indicated planning and learning as central in the RS of the SCI. The dimensional analysis of the interviews with the Biology Undergraduates indicated favourable, contradictory and unfavorable attitudes towards the SCI, associated with images of complexity and dynamism. ECI is represented by Biology Undergraduates as ambiguous, technical application and personal experience.

Keywords: Initial formation; Supervised curricular training; Teaching practice. 


\section{INTRODUÇÃO}

Pela centralidade que ocupam na formação inicial de professores nas licenciaturas o Estágio Curricular Supervisionado (ECS) e a Prática de Ensino são obrigatórios, sendo regulamentados pelo Ministério da Educação (BRASIL, 2002) e pelas Instituições de Ensino Superior. No contexto das mudanças curriculares o Estágio Supervisionado, juntamente com a Prática de Ensino, tornaram-se objetos de atenção, principalmente após a determinação legal de, no mínimo, 800 horas para essas disciplinas nas licenciaturas, bem mais que o dobro em relação ao previsto na Lei de Diretrizes e Bases da Educação Nacional (BRASIL, 1996). Não com poucas resistências, promoveram-se as adequações curriculares nas instituições formadoras tanto em relação à carga horária quanto aos programas das disciplinas e ao quadro docente.

Entre as políticas públicas para instituir um sistema nacional de formação docente, fazer frente às condições adversas da docência e solidificar os esforços da formação nas licenciaturas, foi criado o Programa Institucional de Bolsa de Iniciação à Docência - PIBID. Esse programa objetiva incentivar e valorizar a licenciatura na interação com a educação básica, aproximando os licenciandos das escolas; e conhecer o funcionamento e estrutura das instituições escolares e a sua dinâmica de ensino (JARDILINO, 2014). A aposta dessa iniciativa é, principalmente, a de contribuir para a formação dos licenciandos e valorizar a opção pela docência. Conforme o autor citado, apesar da similaridade que existe entre o PIBID e o ECS, pode instaurar-se conflito entre os dois programas em instituições nas quais eles são aplicados. Foi o que aconteceu em pesquisa desenvolvida por Jardilino (2014) sobre políticas de formação de professores.

Entre os objetivos do ECS, ligados ao contexto escolar, e da docência em escolas de educação básica, estão os seguintes: contribuir para o aprendizado da docência; refletir criticamente sobre o fazer pedagógico e o papel da educação; vincular aspectos teóricos com aspectos práticos do processo de ensinoaprendizagem; compreender o contexto de trabalho da escola onde irá trabalhar futuramente; possibilitar a integração dos trabalhos na relação escola-universidade (ALARCÃO, 1996; JARDILINO, 2014; RODRIGUES, 2013; ROSSO, 2007; ROSSO et al., 2010).

Passada mais de uma década de transformações, é possível analisar as mudanças ocorridas na cultura da formação docente a partir de um quadro curricular e normativo, dos atores envolvidos no estágio supervisionado, do cotidiano em que se desdobram as ações formativas e da sua integração na realidade escolar. Sob tais circunstâncias, os estagiários formam e partilham expectativas, conhecimentos, consensos, dissensos e tensões no espaço formativo sobre o estágio e sobre o que significa estarem na posição de estagiários, os aprendizados e valores associados à formação docente, e a articulação do conteúdo a ser ensinado e suas ações (AMARAL, CARNIATTO, MIGUEL, 2012; BARROS; ALVES; ARAÚJO, 2014).

Assim, de um lado estão os princípios normativos e as propostas do curso com práticas instituídas que determinam o desenvolvimento do ECS e sua cultura instalada na licenciatura; e, de outro, a compreensão dos licenciandos sobre 
o estágio supervisionado, forjada nas complexas relações do conhecimento, do contexto escolar e da sala de aula (PIMENTA, 1995; MELO, MILANESI, 2012, TEIXEIRA, CYRINO, 2013; ALMEIDA, 2014; RAZUCK, ROTTA, 2014). Essa complexidade envolve as transformações dos conhecimentos científicos em conhecimentos ensináveis mediante a compreensão dos alunos em seu contexto e história pessoal, da materialidade das escolas e da docência, dos obstáculos enfrentados por eles na construção e incorporação desses conhecimentos em sua vida, das situações que tornam as ações dos licenciandos muito mais complexas e multideterminadas.

Essa cultura, por estar direta e simultaneamente relacionada às pessoas que experimentam as situações que se desdobram em um quadro instituído, mas que também constroem significados próprios sobre o vivido no interior do curso, da escola e no ECS, contribui para que os estagiários construam suas representações sociais. Assim, com o objetivo de compreender as representações sociais dos licenciandos dos terceiros e quartos anos da Licenciatura de Ciências Biológicas sobre o Estágio Supervisionado, perguntamos: quais são as Representações Sociais que esses alunos, estagiários, possuem sobre o ECS? A participação dos alunos no Programa Institucional de Bolsas de Iniciação à Docência (PIBID) possibilita a eles a formação de uma Representação Social diferenciada sobre o ECS?

\section{REPRESENTAÇÕES SOCIAIS}

A teoria das RS "é uma modalidade de conhecimento particular tendo a função de elaboração dos comportamentos e da comunicação entre os indivíduos" (MOSCOVICI, 2012, p. 27). As RS rompem a barreira entre conhecimento científico e senso comum, partindo da premissa que existem diferentes maneiras de se conhecer e se comunicar, e que a relação indivíduo-sociedade reflete a forma como os indivíduos e os grupos constroem conhecimento sobre os objetos sociais. Os indivíduos e grupos sociais estão constantemente construindo e reconstruindo representações, visto que não são receptores passivos de informação e que não pensam de forma isolada, mas sim em conjunto. Como sujeitos sociais são ativos, criativos e não aceitam simplesmente o que o mundo oferece (MOSCOVICI, 2012).

Nas RS a realidade é uma (re)construção simbólica do sujeito de conceitos, atribuindo novos significados ao objeto representado. Essa (re)construção é também guiada por suas relações e interações sociais, culturais, espaciais e temporais. Assim, o conhecimento que sujeitos e grupos sociais possuem sobre determinado assunto pode ser classificado de acordo com sua função social e pode ser adquirido na "comunicação institucional (os estudos) e não institucionais, e conforme a reciprocidade ou a não reciprocidade das trocas: comunicação direcional (imprensa, rádio) e de impacto ou transitiva (conversação)" (MOSCOVICI, 2012, p. 85). Sendo assim, o conhecimento é construído a partir das trocas sociais e de sua função compreensiva.

As RS sobre o ECS fazem parte do cotidiano dos licenciandos antes de eles entrarem na licenciatura, pela presença de estagiários na Educação Básica, e antes de cursarem a disciplina, pelos comentários dos seus professores e colegas na licenciatura. São representações socialmente construídas por se apoiarem na experiência pessoal, nas informações circulantes no curso e nas normas institucionais, 
fazendo parte simultaneamente das esferas subjetiva, intersubjetiva e transubjetiva (JODELET, 2005, 2007). Assim, o ECS não é apenas um objeto de uma disciplina do currículo, restrito ao professor orientador de estágio e seus alunos, mas de todos os atores que circulam pela licenciatura e pela educação básica, manifestando opiniões, atitudes e juízos de valores sobre ele. Nessa diversidade de interações, os estagiários buscam construir suas verdades a partir dos consensos, das experiências pessoais e da comunicação. Antes de chegarem ao ECS, eles já trazem consigo RS que poderão ser alteradas ou não na disciplina e no campo de estágio.

A análise de uma RS compreende os mecanismos de ancoragem e de objetivação, e inclui as dimensões atitudes, conhecimentos e imagens circulantes sobre o objeto social (MOSCOVICI, 2012). As cognições associadas à ancoragem contemplam a formação de categorias, comparação, generalização e diferenciação sem dissociar afetos, símbolos, atitudes e convenções sociais. O ECS contempla os conhecimentos circulantes que buscam traduzir e se aproximar, transformar e enriquecer com informações o entendimento e o consenso na comunicação. $\mathrm{Na}$ ancoragem o estranho é associado aos esquemas cognitivos anteriores, e ao ECS associam-se os elementos que integram teorias diversas sobre conhecimento, ensino-aprendizagem, formação docente e as ações que fazem parte dele. A ancoragem do ECS integra tanto os conhecimentos oficiais da intencionalidade formativa e normativa quanto das rotinas e práticas circulantes na licenciatura. Em função das interações e denegações, os elementos são organizados e classificados em torno de suas características, necessidades e posicionamentos pessoais.

Com a objetivação os sujeitos materializam o abstrato em algo existente na natureza, convertendo o objeto social em imagem ou comparação. Assim, a dispersão teórica na formação docente é comparada à figura mitológica da Hidra, em matrizes curriculares tidas como verdadeiros "monstros conceituais de várias cabeças" (SILVA, 2010, p. 126), e os subterfúgios institucionais se constituem num labirinto (SILVA; SCHNETZLER, 2008). Receituário e fôrma são as imagens utilizadas para os encaixes da prática e da teoria em pragmatismos e reduções desses campos. O estágio é o ponto nevrálgico na formação (REICHMANN, 2012) e, apesar da complexidade e amplitude, o seu menor prestígio e dos formadores ganha visibilidade no abismo entre as disciplinas teóricas e as práticas de ensino. (PEIXOTO et al., 2014). Ainda, sobre a necessária articulação docente-discente, entende-se que deveria formar "uma engrenagem perfeita entre ambos, o aluno não pode ser visto apenas como um número, mas um ser humano complexo e em formação" (SCALABRIN; MOLINARI, 2013; grifo nosso).

Ancoragem e objetivação são os mecanismos produtores das representações e se expressam nas dimensões conhecimentos, imagens e atitudes. Como conhecimentos e imagens já integraram a descrição formativa, resta explicitar a dimensão atitude. A posição do indivíduo frente a uma determinada situação "independe do grau de informações" que ele detém. Seja favorável, desfavorável, neutra, ou mesmo falsa ou de conveniência, a atitude do indivíduo não tem relação direta com o nível do seu conhecimento sobre determinado assunto (MOSCOVICI, 2012, p. 85). Não se trata apenas de uma resposta, mas de uma "preparação da ação" (p. 44), do que o sujeito vai fazer. Assim, "é a mais frequente das três dimensões e, talvez, geneticamente seja a primeira. Consequentemente [...] 
nos informamos e representamos alguma coisa unicamente depois de ter tomado uma posição e em função desse posicionamento" (p. 69).

A conversação é uma maneira de estabelecer relações e trocas de conhecimento e nela os indivíduos expõem seus conhecimentos, pontos de vistas, experiências sobre suas realidades. Ela é uma atividade experimental e despreocupada da sociedade, como uma realidade em si mesma, em que se trocam "atitudes, tiques, estilos de expressão, o conhecimento se expande" (MOSCOVICI, 2012, p. 92). Os indivíduos têm acesso ao conhecimento nas trocas que ocorrem em diferentes grupos, não só na disciplina de ECS. Nesse sistema de trocas o ECS é reapresentado, atualizado, e seus significados são renovados.

Ao longo do tempo a teoria das representações contou com a contribuição de diversos pesquisadores, fato esse que lhe permite diferentes abordagens (SPINK; 1993; ALVES-MAZZOTTTI, 2008). Uma delas é a abordagem estrutural, também chamada do núcleo central. O núcleo central é constituído pelas expressões mais representativas, socialmente construídas e significativas para os sujeitos, apresentando-se coeso e historicamente determinado. Além do núcleo central, as representações sociais são constituídas por elementos periféricos que são pontuais, da prática diária, sendo maleáveis e diversificados. O núcleo central com caráter normativo e o sistema periférico de ordem funcional (SÁ, 1996).

Desse modo, a busca pelas representações sociais não se limita à sua identificação, mas ao conteúdo a elas conferido. É necessário atuar e compreender a sua organização e a rede de relações sociais a que elas se associam, procurando a hierarquia de elementos que as constituem e as relações que elas estabelecem umas com as outras (ABRIC, 2003).

\section{METODOLOGIA, INFORMACְ̃̃ES COLETADAS E ANALISADAS}

Trata-se, o estudo aqui apresentado, de uma pesquisa de natureza qualiquantitativa com informações coletadas mediante questionário e entrevistas. A aplicação do questionário ocorreu no mês de setembro de 2016 e teve função exploratória; já a entrevista foi aplicada no mês de novembro do mesmo ano, com a função de aprofundamento. O questionário foi organizado a partir da pesquisa de Rosso (2007), com o fornecimento de 106 expressões associadas ao ECS. Dessas expressões os sujeitos deveriam elencar as 20 que consideravam as mais importantes sobre o estágio. Antecedendo os procedimentos de coleta de informações os sujeitos eram solicitados a indicarem a adesão à pesquisa e à divulgação das informações fornecidas, conforme protocolos aprovados pelo Comitê de Ética em Pesquisa. As informações dos participantes do questionário em que não havia essa manifestação foram retiradas das análises.

Após processadas as informações do questionário foram elencadas as 32 expressões mais frequentes para as triagens sucessivas utilizadas nas entrevistas semiestruturadas. Ao todo, participaram da pesquisa 90 informantes dos terceiros e quartos anos das licenciaturas; 70 alunos responderam ao questionário e 20 participaram da entrevista. Responderam ao questionário 24 alunos do $3^{\circ}$ ano da licenciatura de Geografia, 21 alunos do $3^{\circ}$ ano e 25 alunos do $4^{\circ}$ ano da licenciatura de Matemática; e foram entrevistados dez alunos do $3^{\circ}$ ano e dez 
alunos do $4^{\circ}$ ano, participantes ou não participantes do PIBID, na proporção 1:1 da Licenciatura de Ciências Biológicas. Priorizou-se a escolha dos informantes das Ciências Biológicas para o aprofundamento das informações na entrevista por ser esse o espaço de inserção dos pesquisadores.

Figura 1. Fichas utilizadas na triagem hierárquica sucessiva

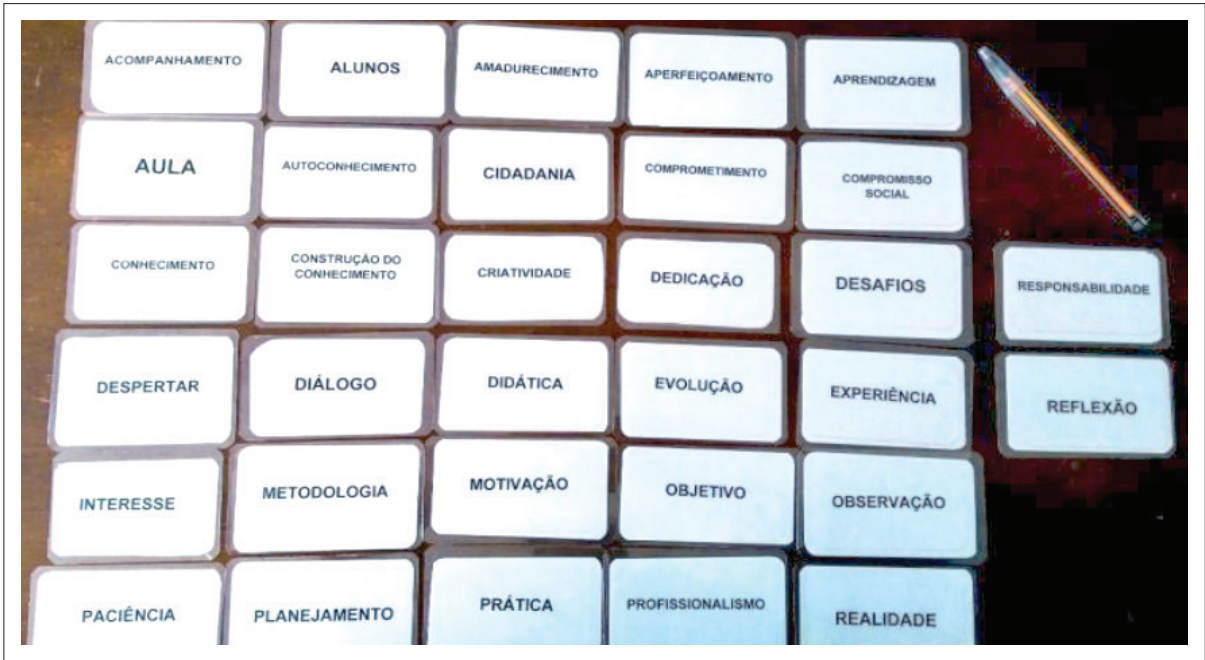

Fonte: Os autores.

Para a primeira etapa foram utilizados os softwares Evoc e o Simi. Do Evoc usou-se o percurso de análise que prepara as informações para a análise de similitude. Ou seja, não foi executado o formato de análise mais frequente, que é o cálculo da frequência e a ordem média de evocação, pois se tratava de um instrumento em que se forneceu uma lista de palavras em ordem alfabética sem solicitar a hierarquização da sua importância, mas que simplesmente se referia à escolha das 20 mais significativas. Em princípio buscaram-se apenas as 32 expressões mais significativas para a realização das entrevistas. A análise de similitude expressa a articulação e o compartilhamento das informações.

Depois de transcritas para a análise, as entrevistas foram preparadas para o processamento no software Alceste, o qual promove a análise lexical do conjunto de informações, com uma dimensão quantitativa, dos elementos textuais; e faz a análise estatística do texto comparando linha a linha e verificando quais variáveis interferem no discurso dos sujeitos. A partir dos relatórios emitidos pelo programa procedeu-se a análise das classes discursivas com base nos cálculos emitidos. Para a análise das atitudes e das imagens associadas ao ECS adotaram-se os procedimentos de análise de conteúdo (BARDIN, 2011; FRANCO, 2005).

\section{PRIMEIRA ETAPA DA PESQUISA: ANÁLISE DOS QUESTIONÁRIOS}

$\mathrm{Na}$ primeira etapa da pesquisa procurou-se identificar o provável núcleo central das representações e os elementos periféricos. As 32 palavras mais frequentes 
apuradas na primeira fase estão em destaque na tabela 1. Entre elas, as dez mais frequentes têm a probabilidade de ocuparem o núcleo central nas representações sociais e estão associadas pelo restante das palavras como elementos periféricos, que possuem relevância na contextualização das situações particulares nas RS dos licenciandos participantes sobre o estágio.

Tabela 1. Listagem das 32 palavras mais frequentes, a partir de 18 ocorrências, dos resultados dos questionários aplicados aos licenciandos de Matemática $(n=46 *)$ e Geografia $\left(n=24^{* *}\right)$

\begin{tabular}{|l|c|c|}
\hline \multicolumn{1}{|c|}{ Expressões } & Freq. & $\%$ \\
\hline Planejamento & 52 & 74 \\
\hline Aprendizagem & 50 & 71 \\
\hline Experiência & 42 & 60 \\
\hline Comprometimento & 40 & 57 \\
\hline Responsabilidade & 38 & 54 \\
\hline Construção do conhecimento & 37 & 53 \\
\hline Didática & 37 & 53 \\
\hline Desafios & 34 & 49 \\
\hline Amadurecimento & 33 & 47 \\
\hline Aperfeiçoamento & 33 & 47 \\
\hline Autoconhecimento & 31 & 44 \\
\hline Realidade & 30 & 43 \\
\hline Acompanhamento & 29 & 41 \\
\hline Observação & 29 & 41 \\
\hline Evolução & 27 & 39 \\
\hline Prática & 27 & 39 \\
\hline Conhecimento & 26 & 37 \\
\hline Criatividade & 26 & 37 \\
\hline Reflexão & 25 & 36 \\
\hline Aula & 24 & 34 \\
\hline Interesse & 24 & 34 \\
\hline Dedicação & 23 & 33 \\
\hline Alunos & 22 & 31 \\
\hline Compromisso social & 22 & 31 \\
\hline Profissionalismo & 21 & 30 \\
\hline Cidadania & 20 & 29 \\
\hline Despertar & 20 & 29 \\
\hline Diálogo & 29 \\
\hline Metodologia & 29 \\
\hline Objetivo & 29 \\
\hline Motivação & 29 \\
\hline Paciência & & 29 \\
\hline
\end{tabular}

Fonte: Dados organizados pelos autores com 0 auxílio do Excel.

* 21 alunos do $3^{\circ}$ ano e 25 alunos do $4^{\circ}$ ano da licenciatura de Matemática.

** 24 alunos do $3^{\circ}$ ano da licenciatura de Geografia. 
Entre as expressões mais citadas, planejamento, didática e aperfeiçoamento se enquadram no grupo de dimensão técnica; aprendizagem, experiência, comprometimento, desafios, responsabilidade e amadurecimento associam-se à dimensão humana do estágio; construção do conhecimento pode ser considerada uma expressão de caráter variável, pois pode se enquadrar em mais de uma dimensão. Nessa etapa a dimensão de caráter político-social não foi destacada. A dimensão humana foi a mais escolhida pelos acadêmicos e está associada à experiência pessoal e à construção da identidade docente (PIMENTA; LIMA, 2008), tendendo a sobressair sobre as outras dimensões do estágio.

Essas informações foram processadas nos programas Evoc e Simi para a organização da árvore de similitude cujos resultados estão disponíveis na figura 2. O filtro de ocorrência simultânea considerou o mínimo de 30\% de compartilhamento entre as escolhas feitas. A árvore apresenta dois núcleos com fortes tendências organizativas das escolhas em planejamento e aprendizagem, os quais possuem 14 arestas e compartilham praticamente todos os elementos que integram a árvore da similitude, escolhidos pelos informantes. Tais elementos são os que têm maior probabilidade de pertencerem ao núcleo central das representações sobre o ECS. Didática, experiência, responsabilidade e comprometimento explicitam as suas ligações (ZANCUL, VIVEIRO, 2012). É importante pontuar a ausência, na árvore de similitude organizada, dos termos escola, alunos, teoria e reflexão, os quais têm significativa relevância nas propostas do ECS.

Figura 2. Representação da árvore de similitude das escolhas dos estagiários de Matemática ( $n=46)$ e Geografia ( $=24$ ), obtida a partir da utilização dos programas Evoc e Simi

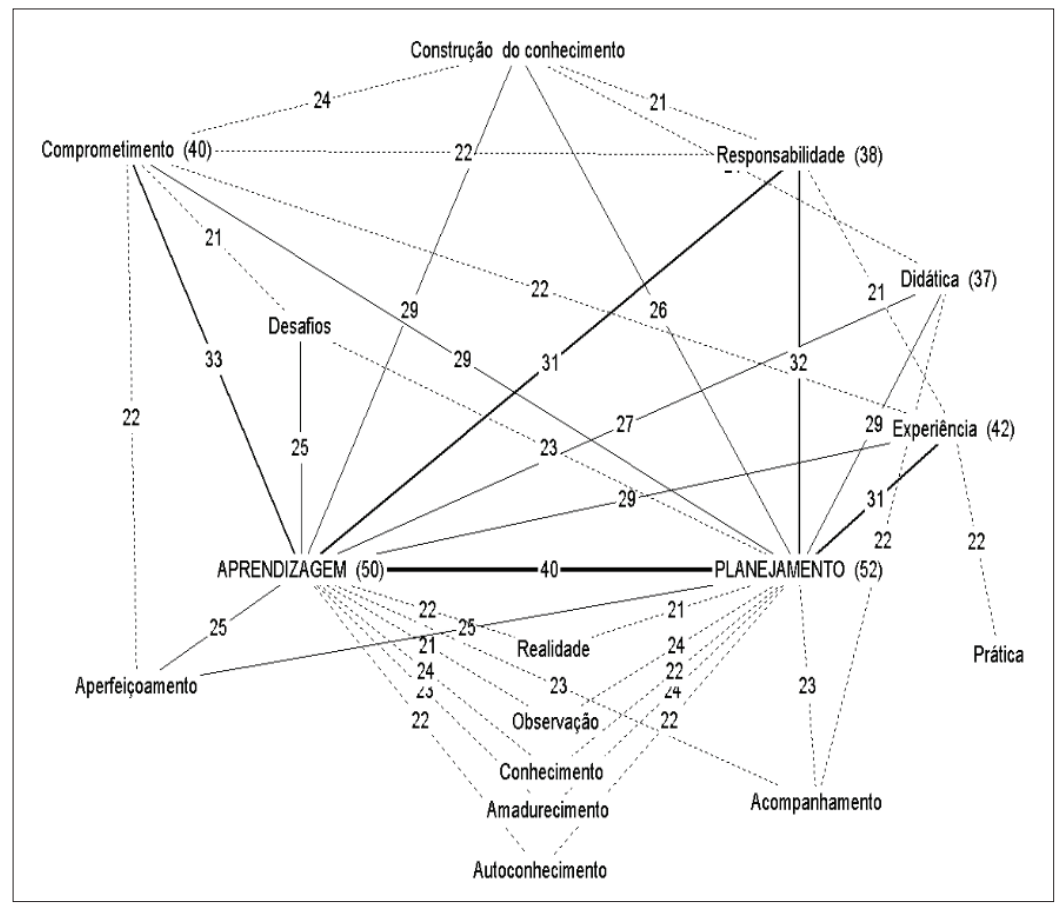

Fonte: Autores 


\section{SEGUNDA ETAPA DA PESQUISA: ANÁLISE DAS ENTREVISTAS}

A segunda etapa procurou abordar os conhecimentos, atitudes e imagens das RS sobre o ECS. A coleta de informações foi realizada mediante entrevistas semiestruturadas, associada a triagens hierárquicas sucessivas das 32 expressões mais importantes apuradas na etapa anterior. No início da entrevista objetivouse o recolhimento de dados censitários dos informantes e o apropriado endosso para a coleta de informações (tabela 2). Na escolha dos licenciandos atendeuse proporcionalmente aos critérios descritos, associados aos de conveniência dos sujeitos (FREITAS et al., 2010).

Tabela 2. Descrição censitária dos sujeitos participantes das entrevistas com licenciandos de Biologia ( $\mathrm{N}=20)$.

\begin{tabular}{|c|c|c|c|}
\hline & Variável & $\mathbf{N}$ & $\%$ \\
\hline \multirow{2}{*}{ Sexo } & Masculino & 5 & 25,0 \\
\hline & Feminino & 15 & 75,0 \\
\hline \multirow{2}{*}{ Série Licenciatura } & Terceiro Ano & 10 & 50,0 \\
\hline & Quarto Ano & 10 & 50,0 \\
\hline \multirow{2}{*}{ PIBID } & Participante PIBID & 10 & 50,0 \\
\hline & Não participante do PIBID & 10 & 50,0 \\
\hline \multirow{2}{*}{ Faixa Etária } & Até 25 anos & 13 & 65,0 \\
\hline & Mais de 25 anos & 7 & 35,0 \\
\hline \multirow{2}{*}{ Trabalho } & Trabalha & 8 & 40,0 \\
\hline & Não trabalha & 12 & 60,0 \\
\hline \multirow{2}{*}{ Trabalho docente } & Atuou como docente & 6 & 30,0 \\
\hline & Não atuou ainda como docente & 14 & 70,0 \\
\hline \multirow{2}{*}{ Estado Civil } & Solteiro & 16 & 80,0 \\
\hline & Casado & 4 & 20,0 \\
\hline \multirow{2}{*}{ Filhos } & Com filho & 2 & 10,0 \\
\hline & Sem filho & 18 & 90,0 \\
\hline \multirow{2}{*}{ Parente educador } & $\begin{array}{l}\text { Possui parente atuante no campo } \\
\text { educacional }\end{array}$ & 19 & 95,0 \\
\hline & $\begin{array}{l}\text { Não possui parente atuando no campo } \\
\text { educacional }\end{array}$ & 1 & 5,0 \\
\hline \multirow{2}{*}{ Escolarização paterna } & Inferior à dos filhos & 16 & 80,0 \\
\hline & Equivalente à dos filhos & 4 & 20,0 \\
\hline
\end{tabular}

Fonte: Dados organizados pelos autores a partir da utilização SPSS.

Apresentamos aos entrevistados as 32 fichas - já mencionadas na metodologia e podem ser observadas na figura 1 - e pedimos que eles selecionassem e separassem as expressões em dois grupos de 16 palavras, um grupo com as palavras mais importantes para eles, sobre o estágio, e o outro com as menos importantes. Das 16 palavras selecionadas como mais importantes, pedimos que novamente escolhessem 
as oito mais importantes e as oito menos importantes. Finalmente, das oito mais importantes, pedimos que escolhessem as quatro expressões mais relevantes sobre o estágio. Dessas quatro, pedimos aos entrevistados que hierarquizassem os itens de acordo com o seu grau de importância em relação ao ECS.

$\mathrm{Na}$ entrevista os sujeitos discorreram sobre as quatro expressões selecionadas nas triagens sucessivas sobre o ECS. Quando essas 32 palavras foram apresentadas aos acadêmicos do curso de Licenciatura em Ciências Biológicas na triagem hierárquica sucessiva, obtivemos a pontuação mostrada na tabela 3. As 11 palavras mais citadas são equivalentes às da tabela 3 .

Tabela 3. Resultado da triagem hierárquica sucessiva das entrevistas com licenciandos de Biologia ( $\mathrm{N}=20$ ).

\begin{tabular}{|c|c|c|c|c|}
\hline Expressões & $1^{\mathrm{a}}$ escolha & $2^{\mathrm{a}}$ escolha & $3^{\mathrm{a}}$ escolha & Pontuação \\
\hline Planejamento & 16 & 12 & 8 & 144 \\
\hline Responsabilidade & 17 & 13 & 6 & 134 \\
\hline Amadurecimento & 16 & 11 & 7 & 132 \\
\hline Aprendizagem & 14 & 10 & 6 & 116 \\
\hline Experiência & 16 & 10 & 4 & 104 \\
\hline Didática & 11 & 8 & 6 & 102 \\
\hline Realidade & 15 & 8 & 5 & 102 \\
\hline Alunos & 12 & 7 & 5 & 92 \\
\hline Reflexão & 14 & 8 & 4 & 92 \\
\hline Comprometimento & 15 & 5 & 3 & 74 \\
\hline Compromisso social & 9 & 6 & 4 & 74 \\
\hline Construção do conhecimento & 13 & 5 & 2 & 62 \\
\hline Profissionalismo & 13 & 5 & 2 & 62 \\
\hline Autoconhecimento & 10 & 4 & 3 & 60 \\
\hline Paciência & 12 & 5 & 2 & 60 \\
\hline Desafios & 11 & 5 & 2 & 58 \\
\hline Conhecimento & 10 & 4 & 2 & 52 \\
\hline Dedicação & 14 & 4 & 1 & 52 \\
\hline Motivação & 8 & 5 & 2 & 52 \\
\hline Prática & 8 & 4 & 2 & 48 \\
\hline Objetivo & 7 & 4 & 1 & 38 \\
\hline Observação & 9 & 3 & 1 & 38 \\
\hline Diálogo & 7 & 2 & 1 & 30 \\
\hline Aperfeiçoamento & 6 & 2 & 1 & 28 \\
\hline
\end{tabular}




\begin{tabular}{lcccc}
\hline Metodologia & 8 & 3 & 0 & $\mathbf{2 8}$ \\
\hline Criatividade & 7 & 2 & 0 & $\mathbf{2 2}$ \\
\hline Evolução & 6 & 2 & 0 & $\mathbf{2 0}$ \\
\hline Aula & 5 & 2 & 0 & $\mathbf{1 8}$ \\
\hline Interesse & 5 & 1 & 0 & $\mathbf{1 4}$ \\
\hline Acompanhamento & 4 & 0 & 0 & $\mathbf{8}$ \\
\hline Despertar & 2 & 0 & 0 & $\mathbf{4}$ \\
\hline Cidadania & 0 & 0 & 0 & $\mathbf{0}$ \\
\hline Total & 320 & 160 & 80 & \\
\hline
\end{tabular}

Obs.: Primeira escolha peso 2, segunda escolha peso 4 e terceira escolha peso 8.

Fonte: Dados organizados pelos autores a partir da utilização do Excel.

Novamente vemos as expressões da dimensão humana como as mais elencadas pelos licenciandos, seguidas das dimensões técnica e político-social. Há o predomínio dos elementos humanos ligados à experiência seguida pela técnica, quando se esperaria um maior equilíbrio entre elas, pois configuram o centro do processo de ensino e aprendizagem e "se exigem reciprocamente" (CANDAU, 1985, p. 21). Esse resultado pode ser atribuído em parte por ser o estágio "um período de adaptação, de vivências, de experiência, de modelagem do perfil do futuro profissional, de alinhamento de ideias e ações" (BARROS, ALVES, ARAÚJO, 2014, p.181).

No resultado da pesquisa de Rosso (2007), a dimensão técnica do estágio é a mais destacada pelos acadêmicos, seguida da dimensão humana e, por último, fica a dimensão político-social. $\mathrm{O}$ autor destaca que na formação de professores não se deve objetivar apenas os aspectos técnicos e metodológicos da profissão, mas o desenvolvimento do professor-educador que saiba integrar os aspectos do contexto social e político de seus alunos na docência. Corroborando com a pesquisa de Rosso (2007), a dimensão político-social possui baixo destaque, o que indica sua localização periférica tanto na compreensão dos licenciandos em Ciências Biológicas, quanto na compreensão dos licenciandos de Matemática e Geografia. Independentemente do tamanho da listagem fornecida para a escolha das expressões que traduzam o ECS sofrem poucas alterações.

O conteúdo transcrito das entrevistas foi processado pelo software ALCESTE e o corpus Estágio Supervisionado originou três classes. A classe 1 descreve elementos do estágio associados à estrutura e ao funcionamento da escola - como a escola funciona, hierarquização das funções dentro do sistema educacional e equipe pedagógica. A classe 2 refere-se à importância do estágio na formação de professores, dando ênfase à aprendizagem adquirida durante o estágio, à experiência, ao amadurecimento e contato com a realidade escolar. Já a classe 3 apresenta as ações do estágio, regências, observações e metodologias de ensino. Em síntese, os espaços das classes são, respectivamente, da Escola, da Universidade e do Estágio. A apresentação das classes dá-se a partir das suas localizações no dendograma e está ilustrada na figura 3. 
Figura 3. Corpus Estágio Curricular Supervisionado formado pelas entrevistas com os licenciados de Biologia ( $N=20)$

\begin{tabular}{|c|c|c|}
\hline \multicolumn{3}{|c|}{$\begin{array}{c}\text { Classe } 1,68 \text { UCE, } 18,13 \% \\
\text { Estrutura e funcionamento } \\
\text { da escola }\end{array}$} \\
\hline Palavras & $\mathrm{n}$ & $x^{2}$ \\
\hline estrutura & 19 & 104,28 \\
\hline funcionar & 21 & 83,11 \\
\hline visualizar & 16 & 54,47 \\
\hline relação & 10 & 46,38 \\
\hline ajuda & 19 & 40,08 \\
\hline escola & 48 & 36,38 \\
\hline diretora & 8 & 31,1 \\
\hline mudar & 15 & 27,45 \\
\hline conhecer & 9 & 23,69 \\
\hline boa & 10 & 22,16 \\
\hline colégio & 9 & 18,45 \\
\hline tranquilo & 4 & 18,25 \\
\hline funcionamento & 21 & 17,81 \\
\hline pedagógica & 6 & 17,81 \\
\hline respeito & 6 & 14,63 \\
\hline família & 3 & 13,65 \\
\hline pública & 6 & 12,13 \\
\hline estágio & 48 & 9,06 \\
\hline colocar & 3 & 8,81 \\
\hline culpa & 3 & 8,81 \\
\hline próxima & 3 & 8,81 \\
\hline realidade & 14 & 7,95 \\
\hline concepção & 4 & 7,31 \\
\hline atençã̃o & 5 & 7,03 \\
\hline diferença & 3 & 5,98 \\
\hline direção & 3 & 5,98 \\
\hline sucesso & 3 & 5,98 \\
\hline interesse & 5 & 5,7 \\
\hline secretaria & 4 & 5,59 \\
\hline perceber & 7 & 5,49 \\
\hline pedagogas & 6 & 4,8 \\
\hline mudança & 3 & 4.17 \\
\hline pibid & 7 & 4,05 \\
\hline
\end{tabular}
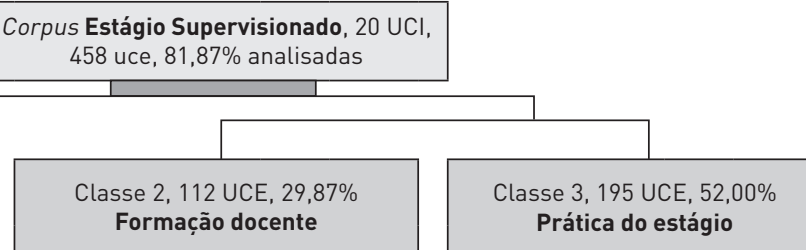

\begin{tabular}{|l|c|c|}
\hline \multicolumn{1}{|c|}{ Palavras } & $\mathrm{n}$ & \multicolumn{1}{c|}{$X^{2}$} \\
\hline importante & 36 & 70,43 \\
\hline formação & 16 & 39,25 \\
\hline considero & 10 & 24,13 \\
\hline responsabilidade & 12 & 21,65 \\
\hline aprendizagem & 13 & 21,07 \\
\hline
\end{tabular}

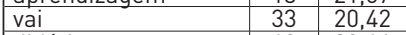

\begin{tabular}{|l|l|l|}
\hline didática & 10 & 20,16 \\
\hline proporciona & 9 & 17,74 \\
\hline
\end{tabular}

\begin{tabular}{|l|c|c|}
\hline proporciona & 9 & 17,74 \\
\hline ceraza
\end{tabular}

\begin{tabular}{|l|l|l|}
\hline certeza & 7 & 16,75 \\
\hline conhecimentos & 4 & 16,38 \\
\hline
\end{tabular}

\begin{tabular}{|l|c|c|}
\hline conhecimentos & 4 & 16,38 \\
\hline experiência & 18 & 15,56 \\
\hline
\end{tabular}

\begin{tabular}{|l|c|c|}
\hline experiência & 18 & 15,56 \\
\hline futuro & 8 & 15,34 \\
\hline
\end{tabular}

\begin{tabular}{|l|c|c|}
\hline prática & 14 & 14,38 \\
\hline adquirir & 6 & 14,32 \\
\hline compromisso
\end{tabular}

\begin{tabular}{l|c|c|}
\hline adquirir & 6 & 14,32 \\
\hline compromisso & 6 & 14,32 \\
\hline
\end{tabular}

\begin{tabular}{|l|c|c|}
\hline gente & 39 & 12,1 \\
\hline amadurecimento & 5 & 11,9 \\
\hline
\end{tabular}

\begin{tabular}{|l|c|c|}
\hline amadurecimento & 5 & 11,9 \\
\hline carga & 5 & 11,9
\end{tabular}

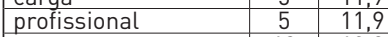

\begin{tabular}{|l|c|c|}
\hline curso & 13 & 10,9 \\
\hline curricular & 6 & 10,62 \\
\hline proissianal
\end{tabular}

\begin{tabular}{|l|c|c|}
\hline curricular & 6 & 10,62 \\
\hline profissional & 5 & 10,62 \\
\hline refletir & 6 & 10,62 \\
\hline
\end{tabular}

\begin{tabular}{|l|c|c|}
\hline profletir & 5 & 10,62 \\
\hline reflir & 6 & 10,62 \\
\hline
\end{tabular}

\begin{tabular}{|l|c|c|}
\hline refletir & 6 & 10,62 \\
\hline social & 6 & 10,62 \\
\hline
\end{tabular}

\begin{tabular}{|c|c|}
\hline aprender & $\frac{0}{20}$ \\
\hline
\end{tabular}

\begin{tabular}{|l|c|c|}
\hline planejar & 7 & 10,11 \\
\hline
\end{tabular}

\begin{tabular}{|l|c|c|}
\hline precisamos & 13 & 9,53 \\
\hline
\end{tabular}

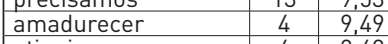

\begin{tabular}{|l|l|l|}
\hline atingir & 4 & 9,49 \\
\hline
\end{tabular}

\begin{tabular}{|l|c|c|}
\hline autoconhecimentos & 4 & 9,49 \\
\hline pode & 22 & 8,83 \\
\hline
\end{tabular}

\begin{tabular}{|l|c|c|}
\hline pode & 22 & 8,83 \\
\hline construção & 5 & 8,32 \\
\hline
\end{tabular}

\begin{tabular}{|l|c|c|}
\hline escolhi & 5 & 8,32 \\
\hline & 5 & 8,32 \\
\hline
\end{tabular}

\begin{tabular}{|l|c|c|}
\hline ambiente & 6 & 7,95 \\
\hline seguir & 7 & 7,9 \\
\hline tenho & 10 & 7,13 \\
\hline
\end{tabular}

\begin{tabular}{|l|c|c|}
\hline seguir & 7 & 7,9 \\
\hline tenho & 10 & 7,13 \\
\hline
\end{tabular}

\begin{tabular}{|l|c|c|}
\hline tenho & 10 & 7,13 \\
\hline acadêmica & 3 & 7,1 \\
\hline comrendendo & 3 & 7,1 \\
\hline compartilhar & 3 & 7,1 \\
\hline
\end{tabular}

\begin{tabular}{|l|l|l|}
\hline compartilhar & 3 & 7,1 \\
\hline graduacão & 3 & 7,1
\end{tabular}

\begin{tabular}{|l|c|c|}
\hline planejar & 12 & 6,8 \\
\hline estágio & 72 & 6,63 \\
\hline
\end{tabular}

\begin{tabular}{|l|c|c|}
\hline conteúdo & 7 & 6,63 \\
\hline disciplina & 8 & 6,45 \\
\hline chegar & 8 & 6,45 \\
\hline
\end{tabular}

\begin{tabular}{|l|c|c|}
\hline chegar & 8 & 6,45 \\
\hline posso & 11 & 6,37 \\
\hline comprometimento & 7 & 6,17 \\
\hline convive & 4 & 6,08 \\
\hline textos & 7 & 4,13 \\
\hline disse & 7 & 4,13 \\
\hline momento & 9 & 4,04 \\
\hline
\end{tabular}

Fonte: Autores, organizada no Excel a partir do Rapport 121 de Alceste.

\begin{tabular}{|c|c|c|}
\hline Palavras & $\mathrm{n}$ & $x^{2}$ \\
\hline falar & 38 & 30,52 \\
\hline marcou & 27 & 23,93 \\
\hline fica & 38 & 21,57 \\
\hline aula & 96 & 21,21 \\
\hline regências & 37 & 20,57 \\
\hline turma & 30 & 17,58 \\
\hline tempo & 28 & 13,8 \\
\hline negativo & 12 & 11,44 \\
\hline parece & 11 & 10,46 \\
\hline problema & 13 & 9,73 \\
\hline lembra & 9 & 8,51 \\
\hline via & 9 & 8,51 \\
\hline ano & 23 & 7,95 \\
\hline pergunta & 11 & 7,81 \\
\hline pretendo & 13 & 7,52 \\
\hline lado & 7 & 6,58 \\
\hline positivo & 7 & 6,58 \\
\hline estagiários & 9 & 5,94 \\
\hline vendo & 9 & 5,94 \\
\hline coisa & 45 & 5,92 \\
\hline horas & 15 & 5,82 \\
\hline terminar & 11 & 5,74 \\
\hline celular & 6 & 5,63 \\
\hline entender & 6 & 5,63 \\
\hline atividades & 18 & 5,43 \\
\hline fiquei & 8 & 5,03 \\
\hline realização & 14 & 5,03 \\
\hline teve & 8 & 5,03 \\
\hline ciências & 12 & 4,91 \\
\hline professora & 98 & 4,89 \\
\hline escolher & 10 & $4, .88$ \\
\hline ensino & 17 & 4,71 \\
\hline carta & 5 & 4,68 \\
\hline feliz & 5 & 4,68 \\
\hline livro & 5 & 4,68 \\
\hline olhando & 5 & 4,68 \\
\hline reclamava & 5 & 4,68 \\
\hline relatório & 5 & 4,68 \\
\hline trabalhos & 5 & 4,68 \\
\hline usar & 5 & 4,68 \\
\hline veio & 5 & 4,68 \\
\hline observação & 23 & 4,54 \\
\hline ler & 7 & 4,13 \\
\hline saia & 7 & 4,13 \\
\hline textos & 7 & 4,13 \\
\hline disse & 9 & 4,04 \\
\hline momento & 19 & 3,93 \\
\hline
\end{tabular}

\begin{tabular}{|l|c|c|}
\hline conviver & 4 & 6,08 \\
\hline lidar & 4 & 6,08 \\
\hline noção & 4 & 6,08 \\
\hline objetivos & 4 & 6,08 \\
\hline sociedade & 4 & 6,08 \\
\hline escolar & 6 & 5,96 \\
\hline seja & 6 & 5,96 \\
\hline tipo & 6 & 5,96 \\
\hline agir & 5 & 5,88 \\
\hline teoria & 12 & 5,82 \\
\hline realidade & 18 & 4,33 \\
\hline horária & 5 & 4,16 \\
\hline primeira & 5 & 4,16 \\
\hline reflexão & 5 & 4,16 \\
\hline passar & 13 & 3,96 \\
\hline caminho & 4 & 3,94 \\
\hline cumprir & 4 & 3,94 \\
\hline
\end{tabular}


A classe 1, Estrutura e funcionamento da escola, recebeu contribuição diferenciada dos licenciandos solteiros e que possuem formação igual ou inferior à dos pais. Os objetos da classe são a estrutura, funcionamento, escola/colégio, equipe pedagógica, direção, secretaria, pública e estágio. As ações associadas aos objetos da classe referem-se às rotinas do sistema educacional, às relações estabelecidas entre professores, pedagogos e a direção, assim como à hierarquização de tarefas. A contribuição do ECS está em visualizar, perceber e conhecer a estrutura e funcionamento da escola, as interações entre os seus segmentos e as atribuições de cada um deles no seu funcionamento. Entre tais atores e espaços, os alunos não se constituem no objeto central dessas ações.

Como observado na análise de dados da primeira fase, a aprendizagem refere-se aos estagiários e não aos alunos da Educação Básica que interagiram durante o ECS, indicando uma percepção a partir do ensino. Apesar de os alunos não constarem como sujeitos nas classes, eles são descritos pelos problemas que causam à estrutura escolar e às ações docentes. Mas, mesmo assim, é relatada a mudança de percepção de que não "era tudo igual e ia ser sempre assim, não ia mudar", mas que "tinha um contraste bem grande nos alunos" (Inf. 15). Os problemas descritos referem-se ao desinteresse, desrespeito e falta de atenção.

Os entrevistados relataram que a partir das interações possibilitadas pelo estágio, perceberam que "muitas coisas não acontecem na escola não é (por) culpa do professor e nem da direção, e sim por questões burocráticas, do governo" (Inf. 2). Reforçam a ideia de que "não se consegue fazer a escola se desenvolver se o Estado não fizer a parte dele, não der a estrutura que a escola precisa" (Inf. 19). Sendo assim, para alguns licenciandos houve mudança na concepção sobre a estruturação e o funcionamento da escola e da educação, pois "nós vemos tudo por trás da sala de aula" (Inf. 16), e não do seu conjunto. É uma leitura da escola em que os licenciandos não se situam como sujeitos externos aos problemas que interferem no aprendizado. Trata-se de uma leitura de baixa ênfase social, pedagógica, e do conjunto de problemas escolares (ROSSO et al., 2010).

Na classe é possível identificar a contribuição do estágio na compreensão das relações entre professores, equipe pedagógica, direção e secretaria, em que "cada um tem uma função" (Inf. 4) dentro da escola. Permanecendo em contato com o ambiente escolar, o licenciando apreende as rotinas da sua futura profissão, o papel do professor dentro do sistema educacional, e como agir frente a "problemas decorrentes da vivência de situações próprias do cotidiano escolar" (SILVA; SCHNETZLER, 2008, p. 2175). Sendo assim, no estágio os licenciandos refletem sobre "o que fazer em cada situação, a quem recorrer, porque isso [...] a gente não aprende nas aulas, aprende mais na escola estando em contato com as professoras e pedagogas" (Inf. 16). Também na classe 1 observa-se que alguns acadêmicos se mostraram reticentes sobre as contribuições do estágio para a compreensão do funcionamento e da estrutura da escola (Inf. 8). Esses acadêmicos relatam que puderam entender como funcionam as aulas de Ciências, mas não a escola como um todo, pois o estágio ajuda mais "com relação [...] à sala de aula, na aula de Ciências" (Inf. 20).

A classe 2, Formação docente, com 29,87\% das informações processadas, recebeu contribuição diferenciada dos licenciandos sem experiência anterior na docência e que estão cursando a primeira graduação, os quais trabalham em áreas diferentes que a do ensino. Em sua maioria, esses licenciandos são do gênero 
masculino e solteiros. Aprendizagem, didática, experiência, prática, teoria e realidade são os substantivos que se destacam na classe e as ações associadas a eles são as seguintes: proporcionar, adquirir, refletir, aprender, planejar, amadurecer, atingir e compartilhar. Importante é o qualificativo que denota atitude frente ao ECS e tem a formação como sua meta.

A experiência e a prática são tidas como condições do aprender e "para você começar a agir e trabalhar na área da educação" (Inf. 19), e é "a partir da experiência que você consegue prever [...] efeitos e resultados do que você fez. [...] (e) vai saber lidar com algumas situaçôes" (Inf. 12). O ECS é definido como importante para a formação por ser considerado "a única experiência que a gente tem antes da formatura, até [...] para ver se a pessoa realmente quer a licenciatura" (Inf. 16). Nesse contexto a teoria é compreendida fora do contexto escolar, da universidade, pois é no ECS que se compreende a "experiência com o ambiente escolar, na faculdade eu vou aprender diversas teorias sobre a educação, didáticas e tudo mais" (Inf. 19).

O ECS é mencionado como essencial na formação docente, visto que representa a oportunidade de confronto com os conhecimentos teóricos; sem ele, o aluno "sairia do curso só com a teoria, sem prática alguma" (Inf. 18). Nas palavras de um informante, o estágio é o "momento do curso em que você vai colocar em prática tudo o que você aprendeu” (Inf. 18). Tais informações conduzem a uma interpretação pragmática em que o ECS está isolado do todo (RODRIGUES, 2013), quando a prática seria o componente curricular que deveria estar integrado às vivências dos ciclos teóricos, em um percurso no qual os licenciandos se exercitariam em todas as disciplinas (PIMENTA, LIMA, 2008) e durante todos os anos da licenciatura (ROSSO, 2007), não só no estágio. Tal pragmatismo clama pela superação dos vazios reflexivos presentes no contexto da formação.

Além de pôr em prática os conhecimentos adquiridos, os licenciandos, no contexto escolar e exercício da docência, podem decidir se é esse o futuro profissional que desejam, pois, o estágio "contribui para que tenhamos certeza da profissão que vamos exercer" (Inf. 15), favorecendo o "amadurecimento de posicionamentos e ideias" (Inf. 11). No estágio ocorre a construção do conhecimento, pois "sempre tem alguma coisa nova que a gente vai aprender lâ" (Inf. 15). Essa aprendizagem pode ser resultado tanto da convivência com os alunos, quanto da convivência com os próprios professores. Esse contato que ocorre na disciplina de estágio pode ser para a maioria dos licenciandos "o primeiro contato com a realidade em sala de aula" (Inf. 7).

Ainda, não dá para deixar de notar entre os informantes uma posição germinal da práxis, ao afirmarem que "a prática e a teoria têm que ser iguais [...] quando você vai trabalhar com um aluno a realidade não é essa, (necessitando) [...] elaborar de novo essa didática para poder trabalhar com os mais diversos alunos" (Inf. 1), ou que "o estagio nos proporciona refletir sobre a nossa própria prática, sobre o porquê estamos fazendo este curso, o que nós queremos para o futuro" (Inf. 13).

A partir dos conhecimentos adquiridos durante o estágio, da convivência com o ambiente escolar, do amadurecimento de ideais, da aprendizagem mútua e das situações vivenciadas na realidade da escola, os acadêmicos adquirem experiência. Aprendem mobilizando conhecimentos e atitudes e, com o passar do tempo, a experiência é adquirida (SILVA; PACCA, 2011) e pode se constituir em "uma experiência única" (Inf. 17). 
A classe 3, Prática do estágio, com 52\% das informações processadas, recebeu contribuição diferenciada dos licenciandos do gênero feminino, que já trabalharam como docentes, possuem formação escolar superior à dos pais, estado civil casado, ou que estão cursando a segunda graduação. Diz respeito aos professores de estágio, aos professores da escola, aos alunos da educação básica e aos estagiários, e refere-se ao conjunto de atividades que compõem o estágio, desde a procura dos estagiários por escolas e professores que os recebam, inserção nas rotinas de turma até o fechamento com o relatório, passando pelas fases de observação das atividades de classe e extraclasse, de apoio ao docente da escola e de regência. Os objetos da classe são aula, regência, horas, atividades, observações, trabalhos e relatório. As ações associadas aos objetos da classe dizem respeito às atividades e práticas associadas ao estágio, sua apreciação e percepção pessoal.

A demarcação observada na classe 2 sobre a teoria, experiência e prática ganha polarização espaço-temporal. Nas aulas da universidade, "os professores trouxeram vários textos sobre a escola, sobre os alunos, reflexões de como é serprofessor, os desafios no ensino de ciências e [...] sala de aula" (Inf. 12); havia "bastante discussão, reflexão sobre os textos e também, às vezes, nós tínhamos que escrever algumas coisas sobre o ensino de ciências e a educação" (Inf. 14). Mas no espaço escolar relata-se que o aprendizado ocorreu "vendo a professora e vou tentar sempre fazer o que ela me ensinou" (Inf. 10); e quanto aos alunos, constatou-se que os estagiários aprovam a "participação deles, que eles ficaram ainda depois da aula perguntando, e eu me surpreendi bastante e eu quero que todas as minhas aulas sejam assim, que os alunos saiam da minha aula fazendo perguntas e curiosos" (Inf. 12).

O estágio contribui na decisão de ser professor/a e aparece nos depoimentos sobre a felicidade em descobrir-se como professor/a e ver a receptividade dos alunos, pegando "gosto pela coisa e escolbi [...] que eu queria ser a muito tempo, só não sabia de qual matéria, então no ensino médio eu decidi que era Biologia" (Inf.12). Ou, de outra forma: "Quero sim ser professora, foram quatro anos que aprendi muito e quero mesmo, ainda mais com os pequenos" (Inf. 10). O depoimento transcrito a seguir reforça a descoberta e a positividade da experiência vivida no estágio: "Os alunos [...] mostraram bastante afeto por mim [...] (na) minha última aula eles levantaram e me aplaudiram [...] essa parte foi bem marcante, bem legal' (Inf. 18).

Os licenciandos relataram a existência de atividades e um cronograma a ser cumprido, no $3^{\circ}$ ano em turmas do Ensino Fundamental - Ensino de Ciências, e no $4^{\circ}$ ano em turmas do Ensino Médio - Ensino de Biologia. Antecedendo o contato com a escola, no espaço da universidade os alunos recebem um conjunto de aulas para orientá-los em atividades futuras. Essas aulas são fundamentais para orientar e criar novas práticas, e não apenas para comprovar, mas também para desmentir e aperfeiçoar a própria teoria. Assim, simultaneamente, as teorias são sustentadas por práticas e as práticas por teorias (PIMENTA, 1995; FELDKERCHER, 2010). Em um primeiro momento os estagiários realizam uma carga horária de observação do contexto da escola, dos alunos e dos professores antes das observações em sala de aulas. Após entender o contexto social em que está inserido, o estagiário executa as regências em espaços extraclasses e em sala de aula. As regências acontecem com a supervisão tanto do professor da escola quanto do professor da disciplina de estágio. Por fim, os acadêmicos registram suas atividades e montam um relatório final de estágio. O estágio não é apenas uma disciplina que deve ser cumprida 
formalmente na licenciatura; ele deve ser entendido e vivenciado, sobretudo, como uma fase excepcional para a formação profissional dos licenciandos (SCALABRIN; MOLINARI, 2013; TOLENTINO, ROSSO, 2014).

A compreensão dimensional das representações sociais integra conhecimentos, atitudes e imagens que os sujeitos possuem sobre o objeto representado (MOSCOVICI, 2012). Os conhecimentos circulantes sobre o estágio supervisionado foram analisados a partir dos relatórios gerados pelo ALCESTE e reportados nas classes que apresentamos. Nessa análise, o PIBID não aparece como variável que interfere no discurso dos entrevistados. Sendo assim, os conhecimentos dos participantes do PIBID não se diferenciam dos conhecimentos dos não participantes do PIBID. A identificação de atitudes e imagens escapa à analise lexical e necessita de análise de conteúdo, pois ambas atitudes e imagens - aparecem ao longo das informações como sinalizadores que extrapolam a linguagem convencional.

As atitudes apresentam-se como favoráveis, contraditórias e desfavoráveis ao estágio. No grupo de atitudes favoráveis destacam-se as que apontam o estágio como essencial e importante para a formação docente, como já mencionado na classe 2: "O estágio é a disciplina mais importante dentre as matérias voltadas a profissionalização [...] porque consegue englobar as duas esferas em um lugar só e você ainda consegue ir para 0 local de atuação de sua futura profissão" (Inf. 13). Os entrevistados também relataram que a realidade vivenciada durante o estágio possibilitou que muitos mudassem suas concepções e visões sobre a educação: "Não queria ser professora [...], mas já me vejo como professora dando aula e atuando como tal. O estágio foi decisivo para [...] a afirmação do que eu quero" (Inf. 20). Outra atitude favorável está associada à mudança de atitude expressa na fala do sujeito 19 "No início eu não pretendia, mas depois da experiência que eu tive no estágio eu acho que eu consigo seguir nessa carreira", e do sujeito 1: "Eu pretendo ser professora com certeza e o estágio me ajudou nesta escolha". A disciplina de estágio é citada na literatura como um "momento de aprendizado riquíssimo", pois é nele que os acadêmicos "ligam" a teoria aprendida na universidade com a prática da sala de aula, adquirem experiência, vivenciam a realidade escolar, visualizam seu futuro como docentes e aprendem novos métodos de ensino, além de conviverem e serem orientados por um professor já formado e em atuação (RODRIGUES, 2013). Esses fatores só reforçam a importância que o estágio possui na formação de professores.

As atitudes contraditórias são aquelas que não se apresentam nem como favoráveis e nem como desfavoráveis, como, por exemplo: "Eu não tenho certeza se o estágio é importante" (Inf. 5), ou "Eu considero o estágio mais ou menos importante, porque no estágio nós vivemos situações diferentes das que um professor vive” (Inf. 8). Isso indica que os dois informantes ainda não têm uma opinião formada sobre a importância do estágio para sua formação. A vivência que o estágio possibilitou também não foi suficiente para mudar a visão deste sujeito: "Depois que terminei o estágio mudou um pouco minha visão" (Inf. 6).

No grupo de atitudes desfavoráveis não identificamos falas que apontam o estágio como indiferente para a formação de professores. Todos os licenciandos entrevistados consideram o estágio importante, nem que seja com alguma restrição. Entretanto, muitos afirmaram que não houve mudança em suas concepções após vivenciarem o estágio, porquanto a sua "percepção sobre a educação permaneceu a mesma, não 
houve uma mudança" (Inf. 5); "durante a realização do estágio eu permaneci com a mesma visão que eu já tinha” (Inf. 9). Alguns ainda afirmaram que o estágio contribuiu para que não quisessem seguir na docência, porque "já tinha alguns pensamentos antes, talvez eu ainda possa mudar de ideia, mas ele contribuiu bastante para eu não querer a docência" (Inf. 14).

Dentre os licenciandos participantes do PIBID vemos um contraste entre atitudes favoráveis, desfavoráveis e contraditórias. Em sua maioria, as atitudes desfavoráveis concentram-se na não mudança de concepção e visão da educação, pois como vivenciaram o cotidiano escolar durante a realização do PIBID, esses licenciandos já conheciam o dia a dia da escola e, durante o estágio, confirmaram sua visão, sem mudanças. Em relação à importância do ECS, todos os licenciandos acreditam que esse estágio é importante, mesmo para quem já possui a experiência do PIBID: "Eu acho o estágio muito importante, o PIBID veio de uma maneira a acrescentar mais a minha experiência, porém os dois são muito diferentes, são programados de maneiras diferentes" (Inf. 9). Os acadêmicos que participam do Programa passam a enxergar a docência como um "campo de pesquisa", e integram pesquisa e ação no diálogo entre universidade e escola (JARDILINO, 2014, p. 358). Questões mais específicas do estágio não são pensadas no PIBID, assim como questões específicas do PIBID não são tão evidentes no estágio, mas ambos trazem contribuições importantes para a formação. No entanto, é importante ressaltar que um não substitui o outro.

As imagens que acompanham o discurso dos sujeitos apresentam complexidade e movimento. A complexidade é expressa na imagem da tabuada, do treinamento, da ilusão de ótica, de caminhos, da diferença, onde vários pontos de vista podem ser analisados. Para o sujeito 8 a imagem que o estágio lembra é de "uma pessoa que quando você está olhando para ela você tem uma imagem, mas quando você olha ela de outro ângulo você percebe que ela não tinha nada a ver com o que você imaginava, como uma ilusão de ótica", ou seja, o estágio parece ser de um jeito, mas na prática é diferente do que se imaginava. Além disso, ao estágio associa-se a imagem de caminhos, dando a oportunidade para que os acadêmicos façam escolhas: "um caminho que te dá oportunidades para você experimentar de tudo e ver o que realmente você quer" (Inf. 20). Segundo o informante 19, o estágio é "como se fosse um treino preparatório [...] que você faz ali, que você se põe na realidade naquele treinamento para aprender a desenvolver as competências".

O movimento é expresso na imagem da bola, que sempre está se movimentando. Segundo o informante 15, "o estágio traz a imagem de uma bola, porque sempre está em movimento, nunca fica parado no mesmo lugar, você pode fazer muitas coisas com ela, e tem várias faces". O movimento também é expresso na imagem de livros e filmes, pois sempre há coisas novas para se descobrir e explorar, não é uma realidade acabada, pronta, está sempre em construção: "O estágio parece a leitura de um livro, porque ele retrata a realidade em si, quando você vê a teoria você consegue imaginar, mas só vai tomar ciência da realidade quando você entra na sala de aula, a mesma coisa de quando você começar a ler um livro, você só vai saber o que acontece realmente quando vivencia tudo" (Inf. 6). O estágio também se expressa na imagem de um professor encantador, que utiliza sua prática para encantar seus alunos, como um mágico. O professor também é citado na imagem do vinho: "Existe dois tipos de professor, aqueles que com o tempo vão ficando melhores e aqueles que azedam, que ficam piores [ ]. Eu quero sempre ser aquele vinho que vai amadurecendo e ficando melhor, que não fica estagnado, que sempre vai mudando seu jeito de ensino, então uma imagem que eu daria para o estágio é a de um vinho" (Inf. 12). 
Também foi possível identificar o despreparo, medo e insegurança dos licenciandos, manifestados na imagem de um jogo de tortura e de cordeiros indo ao abate. O jogo de tortura aparece como uma imagem da relação professor-aluno, em que se esperaria da orientação mais apoio e compreensão do que cobranças e correções, deslocando o plano acadêmico ao de ordem pessoal. Nas palavras do informante: "com a nossa professora é um processo de tortura psicológica, porque é horrivel, muito puxado, tudo está ruim, você se sente um lixo" (Inf. 5). Já a imagem de cordeiros indo para o abate pode ser compreendida como sendo o medo e despreparo dos licenciandos, uma vez que se sentem inseguros para enfrentar a realidade escolar, como "cordeiros indo para o abate, quando o animal vai para o abate ele entra em um corredor e não tem para onde correr a não ser a morte, e às vezes eu me sinto assim saindo da universidade" (Inf. 11). Essa imagem reafirma os relatos de que, ao chegar ao final da licenciatura, os acadêmicos têm pouca experiência profissional, circunstância essa que evidencia ainda mais a importância do estágio como momento de aprendizado e reflexão (RODRIGUES, 2013).

\section{CONSIDERAÇÕES FINAIS}

O conjunto das informações e o percurso de análise manifestam leituras complementares do ECS. Nos instrumentos estruturados os sujeitos o representam a partir do núcleo central aprendizagem e planejamento. Aprendizagem como a via explicativa da experiência pessoal vivida no processo e planejamento como estratégia para o enfrentamento dos obstáculos. Essas mesmas vias são encontradas nas entrevistas, embora com outros termos e com mais detalhamento, sobressaindo nelas a experiência do vivido e o colorido pessoal. Essas nuanças entre grupos e conjunto de informações podem ser atribuídas à natureza dos instrumentos e a aquilo que demanda dos informantes: no primeiro caso, uma tarefa de natureza técnica; e, no segundo, um relato da experiência pessoal.

A representação social dos licenciandos concluintes da Licenciatura em Ciências Biológicas sobre o ECS está ancorada, respectivamente, nas dimensões humana, técnica e político-social. Isso quer dizer que há uma tendência em primeiramente refletir sobre a experiência pessoal vivida durante as ações associadas ao estágio; posteriormente, a elementos didático-pedagógicos; por fim, a elementos periféricos associados a aspectos sociais mais amplos. Os licenciandos idealizam a docência em elementos cotidianos como aprendizagem, responsabilidade, amadurecimento, experiência e comprometimento, ligados às suas vivências no contexto escolar. Em menor frequência, essa idealização acontece em elementos técnicos, como o planejamento e a didática que estruturam e auxiliam a prática e o trabalho do professor. Na periferia da representação há elementos ligados à dimensão político-social, como compromisso social.

$\mathrm{O}$ alinhamento dos conhecimentos, as atitudes e imagens analisadas nos conduzem a três representações sociais. A primeira, favorável ao ECS, é respaldada na experiência adquirida durante a realização do estágio e na descoberta do que os estagiários desconheciam. Junto à experiência está o aprendizado e a satisfação de vencer esse desafio. A segunda representação compreende a frustração e a descoberta de que somente a técnica é insuficiente em sala de aula, uma vez que 
o estágio é bem mais do que a execução de técnicas e metodologias de ensino calcadas no "fazer", e não no processo de compreensão da realidade escolar. A última representação é ambígua, relacionada aos desafios em que os licenciandos resistem e duvidam da importância do ECS, mas, mesmo assim, estão abertos a mudanças de opinião e concepção.

A participação dos sujeitos no Programa Institucional de Bolsa de Iniciação à Docência não contribuiu na constituição das classes com um peso estatístico capaz de diferenciá-los dos demais participantes. Em outros termos, esses sujeitos são portadores da representação social hegemônica comum aos demais licenciandos sujeitos desta pesquisa sobre o ECS. Isso indica que tanto o PIBID quanto o ECS se debatem e competem com a cultura instalada da formação ambiental das Licenciaturas. Nas análises empreendidas as variáveis que tiveram mais peso na constituição das classes foram, em ordem decrescente, o estado civil e o gênero dos licenciandos, se a licenciatura de Ciências Biológicas é a sua primeira ou segunda graduação, se eles atuam como docentes ou não, e o grau de escolaridade dos seus pais.

As representações sociais como: modelo de organização da realidade e das opiniões, filtro de seleção do exterior, orientação das condutas, normas e situações (MOSCOVICI, 2012); “experiência vivida [...] favorecem ou entravam a mudança social" (JODELET 2005, p. 52). As representações sociais como filtro de leitura de mundo podem inspirar sua utilização para "uma mudança baseada na modificação das RS", pois toda a "mudança social, seja qual for a sua escala, supõem a referência a RS” (JODELET, 2007, p. 52-53). Assim, os achados da pesquisa podem subsidiar as práticas de formação e trabalhar, simultaneamente, com elas, ao considerá-las como significativas e verdadeiras construções dos sujeitos e, contra elas, indicando os limites a serem superados e as correções necessárias do modelo formativo.

As informações levantadas e analisadas se constituem num mapa e contribuem para repensar a formação de professores, em geral, e as práticas formativas vivenciadas por estagiários nas Licenciaturas, em particular. Para futuras pesquisas fica o desafio da confirmação ou refutação desses achados em outras licenciaturas e com outros atores sociais ligados ao ECS.

\section{REFERÊNCIAS}

ABRIC, J. C. Abordagem estrutural das representações sociais: desenvolvimentos recentes. In: CAMPOS, P. H. F.; LOUREIRO, M. C. da S. (org.). Representações sociais e práticas educativas. Goiânia: UCG, p. 37-57. 2003.

ALARCÃO, I. Ser professor reflexivo. In: ALARCÃO, I. (org.). Formação reflexiva de professores: estratégias de supervisão. Portugal: Porto Editora, p. 171-189.1996.

ALVEZ-MAZOTTI, A. J. Representações sociais: aspectos teóricos e aplicações à educação. Revista Múltiplas Leituras, v.1, n. 1, p. 18-43, jan./jun. 2008.

AMARAL, A. Q.; CARNIATTO, I.; MIGUEL, K.; SILVA, J. P. B. da. Limites e desafios do Estágio Supervisionado demonstrados em um processo de reflexão num Curso de Licenciatura em Ciências 
Biológicas. Revista Electrónica de Investigación en Educación en Ciencias, vol. 7, núm. 2, p. 13-21, ago./dez. 2012.

BARDIN, L. Análise de conteúdo. São Paulo: Edições 70, 2011.

BARROS, B. H. L. de; ALVES, E. C.; ARAÚJO, R. M. de. Estágio supervisionado em secretariado executivo: a visão do graduando concluinte. Revista de Gestão e Secretariado, v. 5, n. 2, p. 179198, mai./ago. 2014.

BRASIL. Lei no. 9.394, de 20 de dezembro de 1996. Estabelece as diretrizes e bases da educação nacional. Diário Oficial da União, Brasília, DF, 23 dez. Disponível em: < http://www.planalto.gov. br/ccivil_03/Leis/19394.htm>. Acesso em: 12 set. 2016.

BRASIL. Conselho Nacional de Educação. Resolução CNE/CP 1, de 18 de fevereiro de 2002. Institui Diretrizes Curriculares Nacionais para a Formação de Professores da Educação Básica, em nível superior, curso de licenciatura, de graduação plena. Diário Oficial da União, Brasília, 4 mar. 2002. Disponível em: <http://portal.mec.gov.br/seesp/arquivos/pdf/res1_2.pdf>. Acesso em: 15/03/2016. Acesso em: 22 set. 2016.

CANDAU, V. M. A didática e a formação de educadores - da exaltação à negação: a busca da relevância. In: CANDAU, V. M. (org.). A didática em questão. Petrópolis: Vozes, p. 12-22, 1985.

FELDKERCHER, N. O estágio curricular supervisionado como componente teórico e prático em cursos de formação inicial de professores. Revista Espaço Acadêmico, Maringá, v. 10, n. 115, p. 110-116, 2010.

FRANCO, M. L. P. B. Análise de conteúdo. Brasília: Liber Livro Editora, 2005.

JARDILINO, J. R. L. Políticas de formação de professores em conflito com o currículo: estágio supervisionado e PIBID. Educação, Santa Maria, v. 39, n. 2, p. 353-366, maio/ago. 2014.

JODELET, D. Experiência e representações sociais. In: MENIN, M S de S.; SHIMIZU, A. de M. (org.). Experiência e representação social: questões teóricas e metodológicas. São Paulo: Casa do Psicólogo, p. 23-56. 2005.

JODELET, De. Imbricações entre representações sociais e intervenção. In: MOREIRA, A. S. P.; CAMARGO, B. V. (org.). Contribuições para a teoria e o método de estudos das representações sociais. João Pessoa: Editora Universitária UFPB, p. 45-74. 2007.

MELO, M. J. C. de; ALMEIDA, L. A. A. de. Estágio supervisionado e prática docente: Sentidos das produções discursivas da ANPEd, BDTD e EPENN. Revista Eletrônica de Educação, v. 8, n. 4, p. 34-51, 2014.

MILANESI, I. Estágio supervisionado: concepções e práticas em ambientes escolares. Educar em Revista, Curitiba, n. 46, p. 209-227, out./dez. 2012.

MOSCOVICI, S. A psicanálise, sua imagem e seu público. Petrópolis: Vozes, 2012.

PEIXOTO, A. C. de A.; SILVARES, E. F. de M.; ROCHA, M. M. da; MONTEIRO, N. R. de. A Percepção de Estagiários em diferentes IES do Brasil sobre a Supervisão. Psicologia: Ciência e Profissão, v. 34, n. 3, p. 528-539, 2014.

PIMENTA, S. G. O Estágio na Formação de Professores: unidade teoria e prática? Cadernos de Pesquisa, São Paulo, n. 94, p. 58-73, ago. 1995. 
PIMENTA, S. G.; LIMA, M. S. L. Estágio e Docência. 3ª ed. São Paulo: Cortez, 2008.

RAZUCK, R. C. de S. R.; ROTTA, J. C. G. O curso de licenciatura em Ciências Naturais e a organização de seus estágios supervisionados. Ciência \& Educação, Bauru, v. 20, n. 3, p. 739-750, 2014.

REICHMANN, C. L. Práticas de letramento docente no estágio supervisionado de letras estrangeiras. Revista Brasileira de Linguística Aplicada, Belo Horizonte, v. 12, n. 4, p. 933-954, 2012.

RODRIGUES, M. A. Quatro diferentes visões sobre o estágio supervisionado. Revista Brasileira de Educação, v. 18, n. 55, p. 1009-1034, out./dez. 2013.

ROSSO, A. J. Avaliação dos significados atribuídos pelos estagiários à metodologia e prática de Ensino de Biologia. Práxis Educativa, Ponta Grossa, v. 2, n. 2, p. 131-144, julho-dezembro 2007.

ROSSO, A. J.; BRANDT, C. F.; CERRI, L. F.; CAMPOS, S. X. de; FREIRE, L. I. F.; TOZETTO, A. S. Novas Diretrizes Curriculares Nacionais para a formação de professores e algumas novas ficções na leitura da escola. Ensaio: Avaliação e Políticas Públicas em Educação, Rio de Janeiro, v. 18, n. 69, p. 821-842, out./dez. 2010.

SÁ, C. P. de. Representações Sociais: teoria e pesquisa do núcleo central, Temas em Psicologia, Ribeirão Preto, v. 4, n.3, p. 19-33, dez. 1996.

SCALABRIN, I. C.; MOLINARI, A. M. C. A importância da prática do estágio supervisionado nas licenciaturas. Revista Científica, Araras, v. 7, n. 1, p. 1-12, 2013.

SILVA, C. B. da. Atualizando a Hidra? Estágio supervisionado e a formação docente inicial em História. Educação em Revista, Belo Horizonte, v. 26, n. 1, p. 131-156, abr. 2010.

SILVA, R. M. G. da.; SCHNETZLER, R. P. Concepções e ações de formadores de professores de Química sobre o estágio supervisionado: propostas brasileiras e portuguesas. Química Nova, v. 31, n. 8, p. 2174-2183, 2008.

SPINK, M. J. P. O conceito de representação social na abordagem psicossocial. Cadernos de Saúde Pública. v.9, n.3, p. 300-308, 1993.

TEIXEIRA, B. R.; CYRINO, M. C. de C. T. O estágio supervisionado em cursos de licenciatura em Matemática: um panorama de pesquisas brasileiras. Educação Matemática Pesquisa, São Paulo, v.15, n.1, pp.29-49, 2013.

TOlEntinO, P. C.; ROSSO, A. J. As Representações Sociais dos Licenciandos em Ciências Biológicas sobre o Ser Biólogo e o Ser Professor. Ensaio Pesquisa em Educação em Ciências, Belo Horizonte, v. 16, n. 3, p. 15-33, set./dez. 2014.

ZANCUL, M. de S.; VIVEIRO, A. A. O laboratório de ensino de ciências como espaço privilegiado para o planejamento de regência nos estágios supervisionados. Revista Electrónica de Investigación en Educación en Ciencias. v. 7, n. 2, p. 22-29, dez. 2012.

Submetido em 23/11/2017

Aprovado em 02/07/2018

\section{Contato:}

Ademir José Rosso

Rua Henrique Thielen, 61, Jardim Carvalho CEP 84.015-650 - Ponta Grossa, PR - Brasil 